\title{
Pollution characteristics of organic, elemental carbon and water soluble organic carbon in PM2.5 a Tropical City Tiruchirappalli, Tamil Nadu, India
}

\author{
Arun Marimuthu ${ }^{1 *}$, Mohamed Sihabudeen ${ }^{1}$ Shuiping $\mathrm{Wu}^{2}$, Hariharan.G ${ }^{3}$ \\ ${ }^{1}$ Post Graduate and Research Department of Chemistry, Jamal Mohamed College, Bharathidasan University Tiruchirappalli \\ 620020 Tamilnadu, India \\ ${ }^{2}$ College of Environmental and Ecology, Xiamen University, Xiamen 361005, China \\ ${ }^{3}$ National Centre for sustainable coastal management, Ministry of Environment, Forest and Climate Change, Anna University, \\ Chennai, Tamilnadu, India \\ ${ }^{*}$ Corresponding author: ceo@orchard.edu.in Tel: +914312457990
}

Available online at: www.isroset.org

Received: 18/Nov/2018, Accepted: 20/Dec/2018, Online: 31/Dec/2018

\begin{abstract}
Airborne particulate matter has now become an issue in the global environment. In this study, the atmospheric $\mathrm{PM}_{2.5}$, organic carbon (OC), elemental carbon (EC) and water-soluble organic carbon (WSOC) were measured in the urban city of Tiruchirappalli, Tamil Nadu, India. The annual average concentration of $\mathrm{PM}_{2.5}$ was observed in $76.1 \mu \mathrm{g} / \mathrm{m}^{3}$, Similarly, the seasonal average of $\mathrm{PM}_{2.5}$ were $49.4 \mu \mathrm{g} / \mathrm{m}^{3}$ in summer, $73.3 \mu \mathrm{g} / \mathrm{m}^{3}$ in Pre-monsoon, $86.1 \mu \mathrm{g} / \mathrm{m}^{3}$ in winter and $87.9 \mu \mathrm{g} / \mathrm{m}^{-3}$ during monsoon respectively. The present study found that the annual average concentrations of $\mathrm{PM}_{2.5}$ in Tiruchirappalli was significantly higher than the limit of $40 \mu \mathrm{g} / \mathrm{m}^{3}$ prescribed in the National Ambient Air Quality Standards (Indian-NAAQS) and $10 \mu \mathrm{g} / \mathrm{m}^{3}$ of that of the World Health Organization (WHO). While, the annual concentrations of OC, EC and WSOC were 8.9 $\mu \mathrm{g} / \mathrm{m}^{3}, 4.1 \mu \mathrm{g} / \mathrm{m}^{3}$ and $3.1 \mu \mathrm{g} / \mathrm{m}^{3}$ respectively. On seasonal average, the OC and EC concentrations ranked in the order of monsoon> winter>pre-monsoon > summer, which could be attributed to the combined effects of changes in local emissions and seasonal meteorological conditions. The secondary organic carbon (SOC) estimated by EC-tracer method was the highest in pre-monsoon $\left(7.94 \mu \mathrm{g} / \mathrm{m}^{3}\right)$ followed by monsoon $\left(6.60 \mu \mathrm{g} / \mathrm{m}^{3}\right)$, winter $\left(6.04 \mu \mathrm{g} / \mathrm{m}^{3}\right)$ and summer $\left(4.57 \mu \mathrm{g} / \mathrm{m}^{3}\right)$. Overall, results revealed that the mass concentration of PM2.5 bound carbonaceous fractions, and their contributions were varies by seasons. This study provides baseline information that can be exploited for policy formulation and mitigation strategies to control air pollution in south Indian urban cities.
\end{abstract}

Keywords: Urban air quality; fine particulate matter; carbonaceous species; spatial trend; seasonal variation

\section{INTRODUCTION}

In recent decades, the earth's atmosphere is remarkably polluted due to industrialization and urbanization occurring largely in developing countries (1) (2). Urbanization activities involving road transport and construction are widely recognized as a key source of atmospheric particulate matter (PM) pollution in urban cities (3) (4). Atmospheric fine particulate matter $\left(\mathrm{PM}_{2.5}\right)$ has acquired a worldwide attention for its adverse effects on public health and climate change (5) (6). Exposure to $\mathrm{PM}_{2.5}$ has been found to correlate with an enhanced risk of cardio-respiratory diseases (7) (8). On the other hand, the composition and the carbonaceous fraction of PM significantly influence the atmospheric chemistry, resulting in serious climate change impacts (9). Elemental carbon (EC) and organic carbon (OC) are the prominent carbonaceous fractions in aerosols, which are released into 
the atmosphere from anthropogenic combustion as well as biogenic sources (10). EC is found to possess a strong capability of absorbing solar radiation, and it is the second most important contributor to global warming, after $\mathrm{CO}_{2}(11)$. In-addition, watersoluble organic carbon (WSOC) is another component, significantly contributing to carbonaceous aerosol, which may potentially influence the number density of cloud condensation nuclei (12). WSOCs are therefore recognized for altering the radiation balance of the atmosphere (13) (14).

The composition of these carbonaceous fractions of $\mathrm{PM}_{2.5}$ (EC, OC and WSOC) varies significantly based on the spatial distribution and seasonal variations in a given area. Therefore, it is important to understand the influence of these factors in determining the trend of the carbonaceous aerosols in the lower atmosphere. There are several studies that have focused on the carbonaceous aerosols and lower atmospheric air quality in metro cities; whereas, information regarding the variation of carbonaceous aerosols in the urban cities is limited (15) (16) (17) (18). Also, most of the previous research studies reported in the literatures focused on the temporal and spatial variability of trace particle concentrations in urban cities; whereas, the information available on the corresponding trends of carbonaceous aerosols in urban cities is inadequate (19) (20). In this context, the current study focused on the assessment of the influence of spatial and temporal variation on the chemical characteristics and carbonaceous species of $\mathrm{PM}_{2.5}$, in an urban city like Tiruchirappalli. Tiruchirappalli was chosen as the sampling location as it is listed as one of the most polluted cities of Tamil Nadu, with a global ranking of 370 according to the new global urban ambient air pollution ranking released by WHO (21); It is also the fourth largest city of South India, rapidly growing in terms population density and vehicular pollution; Tiruchirappalli is currently facing the challenge of severe air pollution, which has already led to numerous adverse impacts on the atmospheric environment and public health. The main objective of the study was to assess airborne $\mathrm{PM}_{2.5}$ fraction and carbonaceous species in Tiruchirappalli city with emphasis on seasonal variations.

\section{MATERIALS AND METHODS}

\section{Study area}

The Tiruchirappalli city $\left(10.5^{\circ} \mathrm{N}, 78.43^{\circ} \mathrm{E}, 78.8 \mathrm{MSL}\right)$ is situated on the banks of the River Cauvery (Figure 1) Tamil Nadu, South India. Total geographical area of the city is $164.70 \mathrm{~km}^{2}$ with the total population of one million as per 2011 census within its municipal corporation. Tiruchirappalli city has the population in 2017 was around 1.2 million and the total number of vehicles registered with the Regional Transport Authority exceeded 0.7million in 2017. Four major highways NH 45, NH 67, NH 210 and NH 277 pass through the city. The heavy traffic on these highways has significantly contributed to air pollution in the city (19). Sampling was conducted at five sampling sites, located in distinctly different over the Tiruchirappalli city and Figure 1 shows the location of all sampling sites. The sampling locations were selected at Jamal Mohamed College -TVS Tollgate (JMC), Orchard school- KK.Nagar (OrdS), Central Bus stand (CeBS), Thillai Nagar (ThN) and Chathiram Bus Stand (ChBS) (Figure. 1).

The station JMC $\left(10^{\circ} 47^{\prime} 11.72^{\prime \prime} \mathrm{N}, 78^{\circ} 41^{\prime} 40.85^{\prime \prime} \mathrm{E}\right)$ is surrounded by educational and residential buildings, National High way

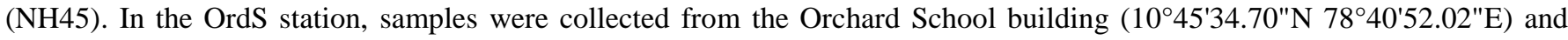
this station was located at the heart of KK Nagar residential area. Also OrdS lies on the outer border of the Tiruchirappalli thus, the new building construction will be the main source of pollution. At the CeBS station, samples were collected at Shri Sangeetha tower which is located near the Central bus stand $\left(10^{\circ} 47^{\prime} 57.63^{\prime \prime N}, 78^{\circ} 41^{\prime} 1.22 " \mathrm{E}\right)$. It is surrounded by scattered inhabited residences and heavy traffic. The ThN station samples were collected from the Cethar Hospital in Thillai Nagar $\left(10^{\circ} 49^{\prime} 26.43^{\prime \prime} \mathrm{N}, 78^{\circ} 41^{\prime} 3.89^{\prime \prime E}\right)$. This site is surrounded by high-rise residential buildings, many hospitals and traffic. Similarly, in ChBS station samples were collected from Hotel Chitra of Chathiram Bus stand (1050'0.65"N, 7841'34.96"E). This site is densely populated with commercial sites and heavy traffic being the city's second bus station next to central bus satation. The samplers were placed on the rooftop of buildings in all sampling sites, about $15 \mathrm{~m}$ height from the ground level. 


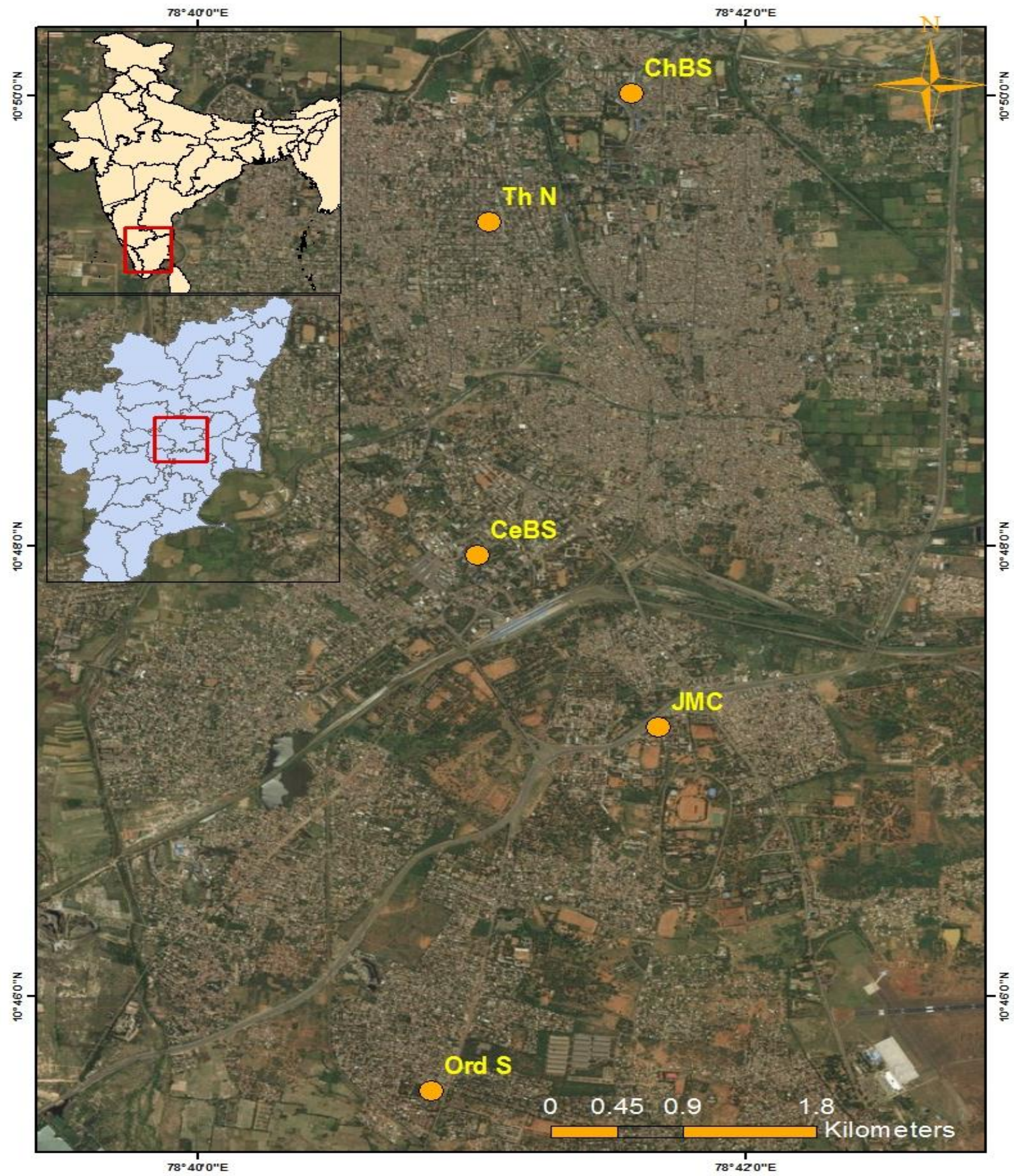

\section{Sample Collection}

Figure 1. Location of the sampling site at Tiruchirappalli, India

Two $\mathrm{PM}_{2.5}$ samplers (TH100-PM2.5 cascade impactor, Wuhan Tianhong Instruments, Wuhan, China) were deployed at each site in parallel. The samples were collected from June 2015 to July 2016, January-February, March-May, June - September and October - December were defined as winter, summer, pre-monsoon and monsoon, respectively. Samples were collected for 24 hours continuously in each station and the flow rate was maintained at $100 \pm 2 \mathrm{~L} \mathrm{~min}^{-1}$. In this study, quartz filters - Whatman, 
QM-A quartz filters $90 \mathrm{~mm}$ (Quartz microfiber filters: Whatman, GE Healthcare Life Sciences, UK.) were used for the analyses of gravimetric, carbon, and WSOC. All blank quartz filters were prebaked at $600^{\circ} \mathrm{C}$ for at least 8 hours in a muffle furnace to remove impurities, and polypropylene filters were used without further treatment (32). $\mathrm{PM}_{2.5}$ mass concentration was obtained by gravimetric method with an analytical microbalance (Mettler Toledo AE420, $\pm 0.01 \mathrm{mg}$ ) after being conditioned under constant temperature and relative humidity. Each filter was stored in a separate sealed Petri dish.

\section{Chemical Analysis}

Carbonaceous species including OC and EC were analyzed by the Thermal/Optical transmittance analyzer (DRI Model 2001 Desert Research Institute, Reno, Nevada, USA) following the temperature program outlined in the NIOSH 5040 method (22). Around $10 \%$ of the samples were randomly selected and measured twice to check the analytical precision. Field blanks were used to quantify procedure detection limits. Trace OC (average $0.98 \mu \mathrm{g} \mathrm{C}$ per punch) and EC (average $0.02 \mu \mathrm{g} \mathrm{C}$ per punch) were detected on the field blank filters. The limits of detection (LOD), calculated as three times of the standard deviation $(3 \sigma)$ of the field blanks, were 0.474 and $0.015 \mu \mathrm{g} \mathrm{C} \mathrm{m}^{-3}$ for OC and $\mathrm{EC}$, respectively, based on $140 \mathrm{~m}^{3}$ of a typical sampling volume per sample. Both carbonaceous species were significantly higher than the LOD in all samples collected. The final carbonaceous mass on each filter was corrected with the field blank.

The remaining half of the merged filter was extracted with $20 \mathrm{~mL}$ organic free Milli-Q water (Millipore Co., Ltd, Shanghai, China) under ultrasonication for $20 \mathrm{~min}$. The extracts were then filtered into a $50 \mathrm{~mL}$ comparison tube using a $0.45 \mathrm{~mm}$ PTFE Acrodisc syringe filter $(13 \mathrm{~mm}$, Pall Co., Ltd, Beijing,China).WSOC in the extract $(10 \mathrm{~mL})$ was quantified using a Total Organic Carbon Analyzer (TOC-VCPH, Shimadzu Co., Ltd, Beijing, China).The instrument was calibrated using a series of sucrose 300 solutions every day through the analysis period.

\section{RESULTS AND DISCUSSION}

\section{Concentration Levels of $\mathrm{PM}_{2.5}$}

The annual average concentrations of $\mathrm{PM}_{2.5}$ in Tiruchirappalli was observed in the range of $74.1 \pm 23.3 \mu \mathrm{g} / \mathrm{m}^{3}$ and the summary of results is presented in Table-1. Moreover, in the study area CeBS $\left(99.8 \mu \mathrm{g} / \mathrm{m}^{3}\right)$ and ChBS $\left(92.9 \mu \mathrm{g} / \mathrm{m}^{3}\right)$ stations were observed significantly higher than other stations. Equally, other stations also observed higher concentrations of $44.8 \mu \mathrm{g} / \mathrm{m}^{3}$, $57.0 \mu \mathrm{g} / \mathrm{m}^{3}$, and $76.0 \mu \mathrm{g} / \mathrm{m}^{3}$ in OrdS, ThN and JMC respectively. The present study signified that the mass of $\mathrm{PM}_{2.5}$ in Tiruchirappalli exceeded the NAAQS $\left(40 \mathrm{ug} / \mathrm{m}^{3}\right)$ and WHO $\left(10 \mathrm{ug} / \mathrm{m}^{3}\right)$ standards. The present higher concentrations of $\mathrm{PM}_{2.5}$ might be attributed to vehicular emissions, biomass burning, re-suspended road dust and other anthropogenic activities. Particularly, the CeBS and ChBS sampling stations are the main transportation hub in the whole city and hence also mark large vehicular movements. In addition, the sampling sites of OrdS, ThN and JMC various local sources including vehicular exhaust, road side restaurants, waste incineration and building construction activities affect the atmosphere. Overall results shows that concentrations of $\mathrm{PM}_{2.5}$ ranked in the order of $\mathrm{CeBS}>\mathrm{ChBS}>\mathrm{JMC}>\mathrm{ThN}>\mathrm{OrdS}$. The present higher concentrations of $\mathrm{PM}_{2.5}$ would cause potential adverse effects to human health (23).

Table. 1 Average seasonal concentrations of the $\mathrm{PM}_{2.5}$ at the five sampling sites $\left(\mu \mathrm{g} / \mathrm{m}^{3}\right)$

\begin{tabular}{lccccc}
\hline Season. & JMC & OrdS & CeBS & ThN & ChBS \\
\hline Winter & 102.3 & 93.2 & 84.3 & 61.8 & 89.1 \\
\hline Summer & 57.6 & 34.5 & 48.6 & 14.7 & 91.8 \\
\hline Pre-monsoon & 66.6 & 45.6 & 125.0 & 56.1 & 73.3 \\
\hline Monsoon & 70.2 & 62.3 & 115.9 & 69.7 & 121.3 \\
\hline Annual Average & $\mathbf{7 6 . 1}$ & $\mathbf{4 4 . 8}$ & $\mathbf{9 9 . 8}$ & $\mathbf{5 7 . 0}$ & $\mathbf{9 2 . 9}$ \\
\hline
\end{tabular}


Generally, the $\mathrm{PM}_{2.5}$ concentration varies considerably with time, location meteorological conditions and source emissions rate (37) (38). The details of meteorological data during the sampling period are presented in Table-2. The average annual rainfall recorded was $2.6 \mathrm{~mm}$. The temperature in winter varies from $22.8^{\circ} \mathrm{C}$ to $34.7^{\circ} \mathrm{C}$ and in summer the range of $36.40^{\circ} \mathrm{C}$ to $41.10^{\circ} \mathrm{C}$., in pre-monsoon $26.3{ }^{\circ} \mathrm{C}$ to $37.6{ }^{\circ} \mathrm{C}$, and in monsoon $23.6{ }^{\circ} \mathrm{C}$ to $30.9^{\circ} \mathrm{C}$. Fig. 2 (a), (b), (c) and (d) presents the wind rose diagram for winter, summer, pre-monsoon and monsoon seasons, respectively. During winter and monsoon, air masses flow from NE, whereas, summer and pre-monsoon the wind flow from SW directions. During summer and pre-monsoon similar wind speed recorded 4 to $7 \mathrm{~m} / \mathrm{s}$, whereas monsoon and winter the wind speed varied from 7 to 11,11 to $17 \mathrm{~m} / \mathrm{s}$ respectively. Similarly, wind speed was found to be low during summer and pre-monsoon seasons and gradually increased during monsoon and winter. Frequent changes in wind force increases the atmospheric turbulence during summer months, thereby increasing the dispersion of $\mathrm{PM}_{2.5}$ emissions. The present study has shows that, significant seasonal variations of $\mathrm{PM}_{2.5}$ are controlled by meteorological factors.
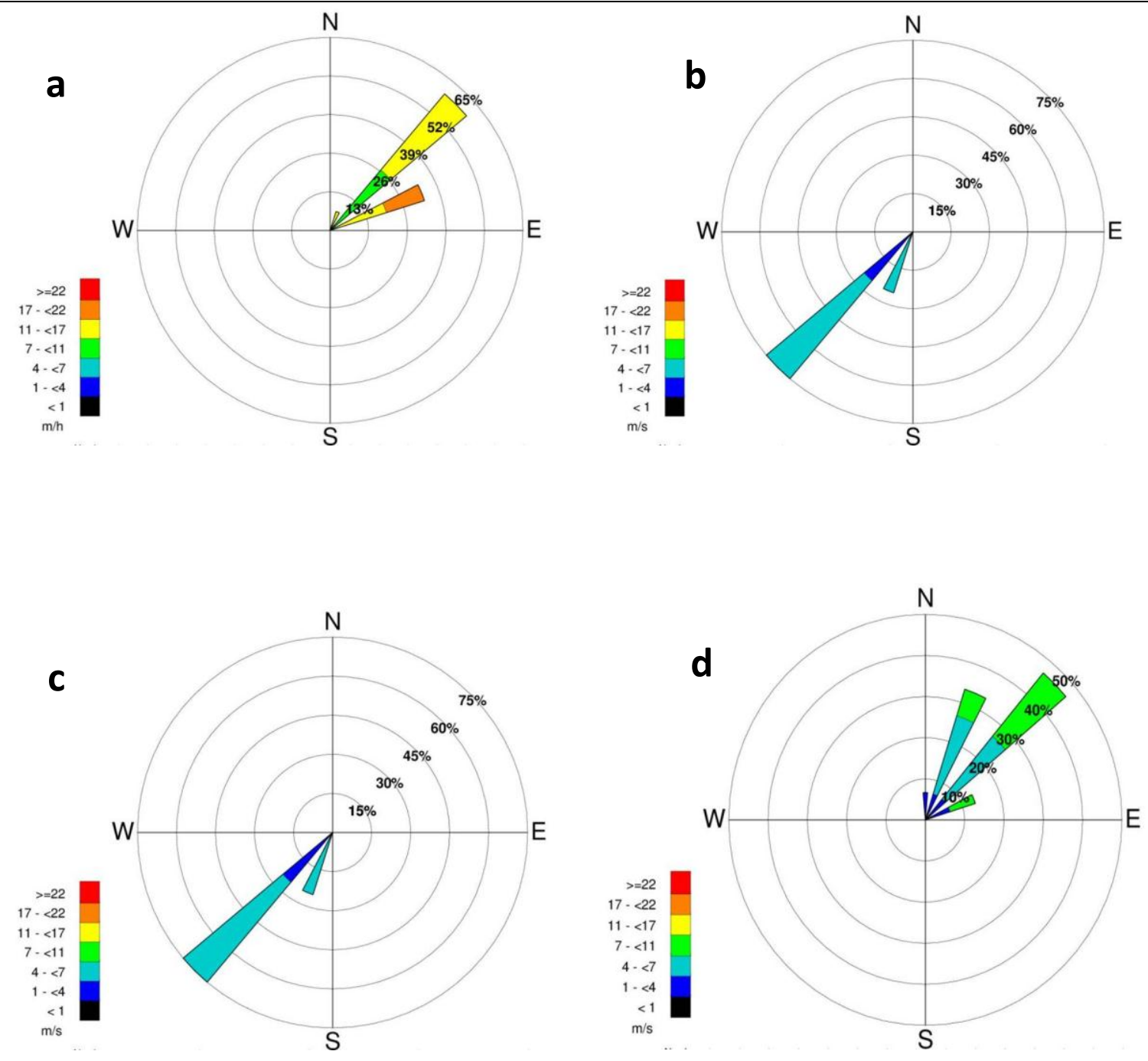

Figure 2. Seasonal wind-rose diagram of sampling sites - (a) winter, (b) summer, (c) pre-monsoon and (d) monsoon seasons.

Table 2. Meteorological condition in Tiruchirappalli during the study period (July 2015-July 2016) 


\begin{tabular}{|c|c|c|c|c|c|}
\hline \multicolumn{2}{|l|}{ Season } & $\begin{array}{c}\text { Temperature } \\
\qquad\left(C^{0}\right)\end{array}$ & $\begin{array}{c}\text { Humidity } \\
(\%)\end{array}$ & $\begin{array}{c}\text { Wind speed } \\
(\mathbf{k m} / \mathbf{h})\end{array}$ & Rain fall (cm) \\
\hline & Minimum & 34.7 & 37.3 & 7.1 & 0.1 \\
\hline \multirow[t]{3}{*}{ Winter } & Maximum & 22.8 & 74.9 & 8.3 & 0.0 \\
\hline & Average & 28.7 & 56.1 & 7.7 & 0.1 \\
\hline & Minimum & 24.1 & 46.2 & 6.7 & 0.1 \\
\hline \multirow[t]{3}{*}{ Summer } & Maximum & 36.9 & 73.9 & 8.4 & 5.3 \\
\hline & Average & 31.0 & 60.1 & 7.6 & 3.0 \\
\hline & Minimum & 26.3 & 41.0 & 8.9 & 0.1 \\
\hline \multirow[t]{3}{*}{ Pre-monsoon } & Maximum & 37.4 & 65.0 & 12.8 & 3.5 \\
\hline & Average & 31.8 & 54.6 & 10.7 & 2.0 \\
\hline & Minimum & 23.6 & 75.1 & 5.7 & 2.4 \\
\hline \multirow[t]{2}{*}{ Monsoon } & Maximum & 30.9 & 85.7 & 6.3 & 8.3 \\
\hline & Average & 27.2 & 80.4 & 6.0 & 6.3 \\
\hline
\end{tabular}

With respect to meteorological behaviors, the seasonal average concentration of $\mathrm{PM}_{2.5}$ at Tiruchirappalli City was observed to be $86.1 \pm 13.6 \mu \mathrm{g} / \mathrm{m}^{3}$ in winter, $49.4 \pm 25.6 \mu \mathrm{g} / \mathrm{m}^{3}$ in summer, $73.3 \pm 27.5 \mu \mathrm{g} / \mathrm{m}^{3}$ in pre-monsoon and $87.9 \pm 25.3 \mu \mathrm{g} / \mathrm{m}^{3}$ in monsoon, respectively. The concentrations of $\mathrm{PM}_{2.5}$ at the five stations revealed a typical seasonality with higher values in winter, monsoon followed by pre-monsoon and lower values in summer. This seasonal variation could be attributed to the effects of changes in emissions rate and seasonal metrological conditions. It is clear that prevailing wind direction is southsouthwest in summer and pre-monsoon and north-northeast in other seasons. In addition to these anthropogenic emissions, the steady meteorological conditions during winter season (high RH and low wind speed) favor the accumulation of particles (24). Furthermore, in winter, due to lower ambient temperatures, lower mixing depths, temperature inversion and foggy conditions, low, calm condition and higher consumption of fuel augments the pollution (25). The results of this study the $\mathrm{PM}_{2.5}$ concentrations were directly compared with those measured in other cities in India, the $\mathrm{PM}_{2.5}$ concentration (Table 3) in Tiruchirappalli city was at a moderately higher level.

Table. 3 Summary of $\mathrm{PM}_{2.5}$ concentrations over various sites in India.

\begin{tabular}{lllll}
\hline Study Area & Area type & Time period & $\boldsymbol{P M}_{2.5}\left(\boldsymbol{\mu g} / \mathbf{m}^{\mathbf{3}}\right)$ & References \\
\hline \multirow{4}{*}{ Trichirappalli } & \multirow{2}{*}{ Urban } & Winter & 86.1 & \\
& & Summer & 49.4 & \multirow{2}{*}{ Present study } \\
& & Pre-monsoon & 73.3 & \\
& & Monsoon & 87.9 & \multirow{2}{*}{ Balakrishaiah et.al } \\
Anantapur & \multirow{2}{*}{ semi-urban } & winter & 21.29 & $(2011)$ \\
& & Pre-Monsoon & 16.34 & \\
\hline
\end{tabular}




\begin{tabular}{|c|c|c|c|c|}
\hline Chennai & Urban & $\begin{array}{l}\text { Winter } \\
\text { Pre-Monsoon } \\
\text { Post-Monsoon }\end{array}$ & $\begin{array}{l}36-148 \\
14-94 \\
61-126\end{array}$ & $\begin{array}{l}\text { Bathmanabhan et al. } \\
\text { (2010) }\end{array}$ \\
\hline Trivandrum & Coastal & $\begin{array}{l}\text { Winter } \\
\text { Pre-monsoon } \\
\text { Monsoon } \\
\text { Post-monsoon }\end{array}$ & $\begin{array}{l}54.1 \\
45.2 \\
28.1 \\
39.7\end{array}$ & Pillai et al.(2002) \\
\hline Pune & Urban & $\begin{array}{l}\text { Summer } \\
\text { Monsoon } \\
\text { Post-monsoon } \\
\text { Winter }\end{array}$ & $\begin{array}{l}123.3 \\
92.9 \\
143.3 \\
101.5\end{array}$ & Pipal et al. (2016) \\
\hline Jabalpur & Urban & $\begin{array}{l}\text { Winter } \\
\text { Pre-Monsoon } \\
\text { Monsoon }\end{array}$ & $\begin{array}{l}62.0 \\
42.6 \\
25\end{array}$ & Panicker et al. (2015) \\
\hline Udaipur & Urban & Winter & 59 & Panicker et al. (2015 \\
\hline Hyderabad & Urban & $\begin{array}{l}\text { Winter } \\
\text { Pre-monsoon } \\
\text { Monsoon } \\
\text { Post-monsoon }\end{array}$ & $\begin{array}{l}22-38 \\
22-38 \\
8-38 \\
30-32\end{array}$ & $\begin{array}{l}\text { Latha and Badarinath } \\
(2005)\end{array}$ \\
\hline Guwahati & Urban & $\begin{array}{l}\text { July } 2013 \text { to June } \\
2014 \\
\text { Summer } \\
\text { Autumn } \\
\text { Winter } \\
\text { Spring }\end{array}$ & $\begin{array}{l}52-90 \\
19-36 \\
48-74 \\
99-156 \\
53-110\end{array}$ & S.Tiwari et al (2016) \\
\hline
\end{tabular}

\section{Concentrations and seasonal variations of OC, EC and WSOC}

Atmospheric ecosystems are closely coupled with global climate, particularly by carbon cycling between vegetation, soils and the atmosphere (26). Correspondingly, several factors are known to influence the variations in atmospheric carbon concentration, and the present study reveals a clear picture of recent change and trends within the study area. The annual average concentrations of OC, EC and WSOC were $8.95 \pm 3.59 \mu \mathrm{g} / \mathrm{m}^{3}, 4.10 \pm 2.31 \mu \mathrm{g} / \mathrm{m}^{3}$ and $3.07 \pm 0.95 \mu \mathrm{g} / \mathrm{m}^{3}$ with their variations ranging from 3.99 to $16.32,0.63$ to 8.53 and 1.33 to $5.59 \mu \mathrm{g} / \mathrm{m}^{3}$ respectively (Table 4).EC concentrations in $\mathrm{PM}_{2.5}$ ranked in the following order: JMC $>\mathrm{CeBS}>\mathrm{ChBS}>\mathrm{ThN}>\mathrm{OrdS}$. The higher EC concentrations in JMC, CeBS and ChBS indicate high vehicular exhaust on those sites. The average concentrations measured on each location considerably high could be attributed to the mixed contributions of emissions from heavy traffic flows, road side restaurants and open burnings. Present $\mathrm{OC}$ and EC concentrations of $\mathrm{PM}_{2.5}$ were similar to those measured in Xiamen-Putian, Tianjin-China, Hong Kong and Seoul (27) (28) (29). Whereas, OC and EC concentration was lower than the Indian cities, those measured in the Indo Gangetic Plain (30), Jabalpur \& Udaipur (31), Agra (32), Delhi (33) and Pune (34). WSOC is one of the major components of the total watersoluble composition of atmospheric aerosols, contributing to the number density of cloud condensation nuclei (CCN). In the present study, WSOC concentration ranged from $1.13 \mu \mathrm{g} / \mathrm{m}^{3}$ to $5.59 \mu \mathrm{g} / \mathrm{m}^{3}$ and the abundance contributes $34.83 \%$ of OC at Tiruchirappalli, which was comparable to those reported in the literature for other urban sites (35) (36). The abundance pattern of WSOC is similar to that of the North Indian urban cities Allahabad and Kanpur (37). 
Furthermore, the annual average concentration of OC, EC and WSOC in $\mathrm{PM}_{2.5}$ in study area was in the following range, JMC $\left(7.46 \mu \mathrm{g} / \mathrm{m}^{3}, 5.84 \mu \mathrm{g} / \mathrm{m}^{3} \& 3.28 \mu \mathrm{g} / \mathrm{m}^{3}\right)$ OrdS $\left(8.98 \mu \mathrm{g} / \mathrm{m}^{3}, 3.15 \mu \mathrm{g} / \mathrm{m}^{3} \& 3.48 \mu \mathrm{g} / \mathrm{m}^{3}\right) \mathrm{CeBS}\left(11.22 \mu \mathrm{g} / \mathrm{m}^{3}, 4.47 \mu \mathrm{g} / \mathrm{m}^{3} \& 3.27\right.$ $\left.\mu \mathrm{g} / \mathrm{m}^{3}\right) \operatorname{ThN}\left(7.25 \mu \mathrm{g} / \mathrm{m}^{3}, 3.35 \mu \mathrm{g} / \mathrm{m}^{3} \& 2.40 \mu \mathrm{g} / \mathrm{m}^{3}\right)$ and ChBS $\left(9.88 \mu \mathrm{g} / \mathrm{m}^{3}, 3.72 \mu \mathrm{g} / \mathrm{m}^{3} \& 2.91 \mu \mathrm{g} / \mathrm{m}^{3}\right)$ respectively. The seasonal mean concentrations of $\mathrm{OC}$ were higher than those EC, and both had a large variation. The temporal variability in the mass concentrations of OC, EC and WSOC in $\mathrm{PM}_{2.5}$ is presented in Fig. 3 In fine-mode OC concentration varied $5.8 \mu \mathrm{g} / \mathrm{m}^{3}$ in summer, $7.7 \mu \mathrm{g} / \mathrm{m}^{3}$ in pre-monsoon, $9.7 \mu \mathrm{g} / \mathrm{m}^{3}$ in winter and $12.6 \mu \mathrm{g} / \mathrm{m}^{3}$ in monsoon. The concentration of EC range varied from $1.9 \mu \mathrm{g} \mathrm{C} / \mathrm{m}^{3}$ in summer, $3.0 \mu \mathrm{g} / \mathrm{m}^{3}$ in pre-monsoon, $4.7 \mu \mathrm{g} / \mathrm{m}^{3}$ in winter to $6.8 \mu \mathrm{g} / \mathrm{m}^{3}$ in monsoon. The concentrations of WSOC varied from $2.6 \mu \mathrm{g} / \mathrm{m}^{3}$ in pre-monsoon and summer, $3.2 \mu \mathrm{g} / \mathrm{m}^{3}$ in winter to $3.7 \mu \mathrm{g} / \mathrm{m}^{3}$ in monsoon. During summer, OC and EC concentrations are nearly 2-3 times lower than those during winter and monsoon.

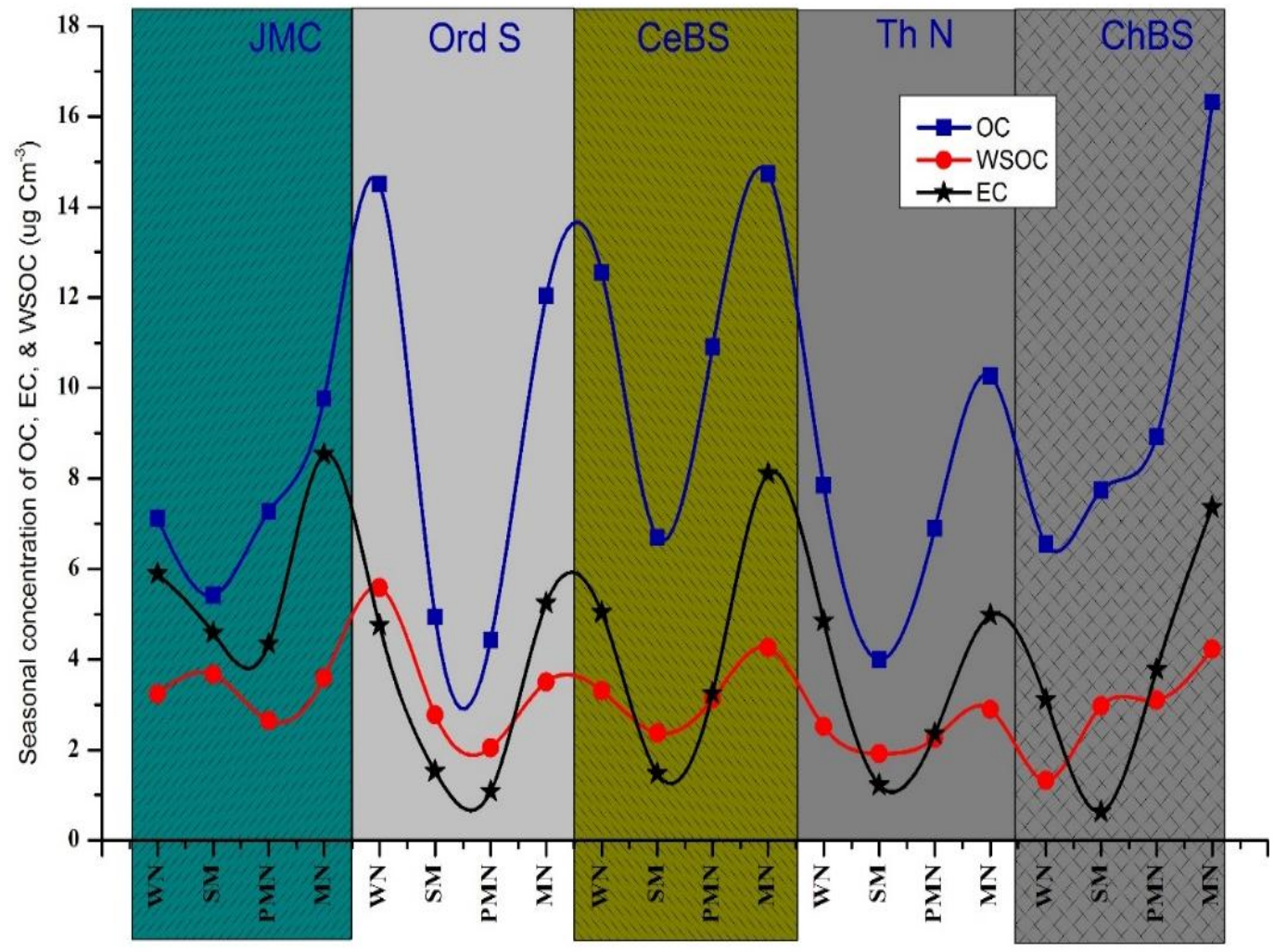

Season

Figure 3. Seasonal mean concentrations of OC, EC, WSOC $\left(\mu \mathrm{g} / \mathrm{m}^{3}\right)$ in Tiruchirappalli.

Seasonal variations of OC, EC and WSOC concentrations were significant, with the descending order: monsoon > winter > pre-monsoon > summer. The lowest concentrations of OC, EC and WSOC occurred in summer. The highest concentrations of carbonaceous species appeared in monsoon and winter, and the mean OC, EC and WSOC concentrations in monsoon were 2.2 times, 3.6 times and 1.3 times as high as that in summer, respectively. In general, mass concentrations of OC and EC, are higher in monsoon and winter and significantly lower in summer and pre-monsoon. The higher concentrations found in monsoon and winters could be attributed to the biomass burning after harvest and low atmospheric boundary layer height conditions and low dispersion rate in Tiruchirappalli. The results are in agreement with those observed that the abundance of WSOC relative to OC could be employed as an indicator to decipher whether organic aerosol is primary or secondary, because SOC usually tends to be more water soluble than primary organic matter (38).

\section{OC/EC and WSOC/OC Ratios and Source Characteristics}

Organic and elemental carbon ratio (OC/EC) provides an idea to identify the possible sources of carbonaceous aerosols. Higher OC/EC ratios are used as an indicator of biomass burning sources while lower ratio are linked with fossil fuel combustions, hence OC/EC ratios could be used to make out different source and transformation characteristics (39). Sandradewi et al., reported an average OC/EC ratio of 7.3 for wood burning and 1.1 from vehicular emissions. Similarly, Watson et al., (40) found an OC/EC ratio of 2.7 for coal combustion, 9.0 for biomass burning. The present study, the ratio of OC/EC was in the 
range of $1.21-3.05,1.18-4.55,1.68-4.08$ and 1.14-2.3, with average of 2.1, 3.2, 2.9, 1.9 in winter, summer, pre-monsoon and monsoon respectively. Figure 4 illustrate the ratios of OC/EC in different seasons along the study area. It shows that the OC/EC ratios in summer, pre-monsoon and monsoon were greater than 2, and winter has the OC/EC ratio slightly lower than 2. Summer had the highest ratio and winter had the lowest ratio, which matches the findings by Zhao et al. (4). Usually, the SOC can be formed when the ratio of $\mathrm{OC} / \mathrm{EC}$ is over 2 (41). In this study, the OC/EC ratio varied from 1.21 to 4.55 within an average of 2.51. These ratios clearly indicate that the impact of vehicular emission and biomass burning was more prominent in the present samples.

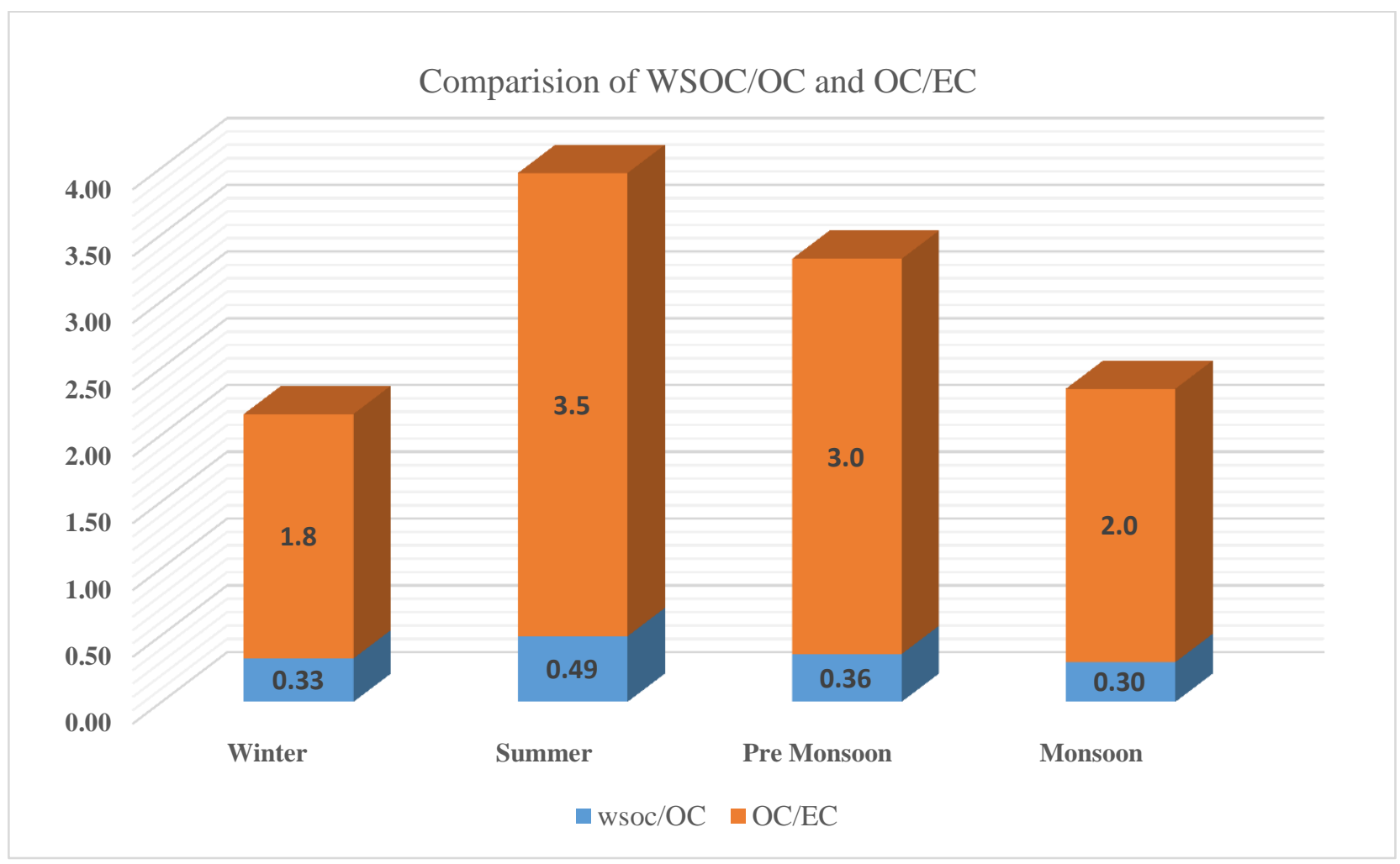

Figure 4. Seasonal ratio of WSOC/OC and OC/EC

Similarly, WSOC/OC ratios ranged from 0.20 to 0.68 with an average of $0.37 \pm 0.11$ and suggested that the possible sources of WSOC include primary combustion emissions and secondary formation (42). The present study, the ratio of WSOC/OC was in the range of $0.20-0.45,0.35-0.65,0.29-0.46$ and $0.26-0.37$, with an average of $0.33,0.49,0.36$ and 0.30 in winter, summer, premonsoon and monsoon respectively. Figure 4 illustrate the ratios of WSOC/OC in different seasons along the study area. A large spread in WSOC/OC ratios further suggests temporal variability in emission sources, their strength, and contribution from SOC sampling site. The WSOC/OC ratios are a unique tracer to understand secondary organic carbon (SOC) formation mechanism (43) (. It has been postulated that relatively high WSOC/OC ratios during summer months indicate contribution from SOC due to increased photochemical activity and/or aging of aerosols during the long-range atmospheric transport. As expected, higher OC/EC and WSOC/OC ratios were found in summer than in winter (Table, 4). The higher WSOC/OC slope in the summer than in winter suggests that secondary organic carbon formation processes produce significant amounts of WSOC during summer. Information on the WSOC partitioning between its primary and secondary fraction can be derived by means of the EC tracer method.

Table.4 Mass concentrations (in $\mu \mathrm{g} / \mathrm{m}^{3}$ ) of OC, EC and WSOC along with OC/EC and WSOC/OC ratios at study area. 


\begin{tabular}{|c|c|c|c|c|c|c|c|c|}
\hline & \multicolumn{2}{|c|}{ Winter } & \multicolumn{2}{|c|}{ Summer } & \multicolumn{2}{|c|}{ Pre-Monsoon } & \multicolumn{2}{|c|}{ Monsoon } \\
\hline & Min & $\operatorname{Max}$ & Min & $\operatorname{Max}$ & Min & $\operatorname{Max}$ & Min & $\operatorname{Max}$ \\
\hline Mass of $\mathrm{PM}_{2.5}$ & 44.8 & 99.79 & 14.72 & 91.78 & 56.07 & 124.98 & 62.32 & 121.33 \\
\hline $\mathrm{OC}$ & 6.55 & 14.50 & 3.99 & 7.74 & 4.43 & 10.91 & 9.77 & 16.32 \\
\hline EC & 3.11 & 5.89 & 0.63 & 4.59 & 1.09 & 4.34 & 5.24 & 8.53 \\
\hline WSOC & 1.33 & 5.59 & 1.92 & 3.67 & 2.05 & 3.10 & 2.89 & 4.23 \\
\hline OC/EC & 1.21 & 3.05 & 1.18 & 4.55 & 1.68 & 4.08 & 1.14 & 2.30 \\
\hline WSOC/OC & 0.20 & 0.45 & 0.35 & 0.68 & 0.29 & 0.46 & 0.26 & 0.37 \\
\hline
\end{tabular}

\section{Estimation of the Secondary Organic Carbon (SOC)}

The present study, contribution of secondary organic carbon (SOC) was estimated using an EC tracer method (44) (4) (45).

SOC $=$ OC-EC x (OC/EC) pri

Where $(\mathrm{OC} / \mathrm{EC})_{\text {pri }}$ is the ratio for primary sources contributing to $\mathrm{PM}_{2.5}$. Following the method in Feng et al. (46) and Li et al., (45), the values of (OC/EC) pri were simplified as the smallest observed ratio in the range of 1.21-4.55. These (OC/EC) pri ratio were comparable with $2.2-5.3$ in Feng et al (46) but higher than $1.27-1.85$ in Li et al., (45).

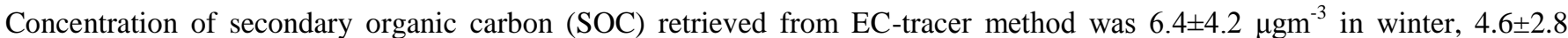
$\mu \mathrm{g} . \mathrm{m}^{-3}$ in summer, $7.9 \pm 3.2 \mu \mathrm{g} . \mathrm{m}^{-3}$ in pre-monsoon and $6.6 \pm 3.3 \mu \mathrm{g} \cdot \mathrm{m}^{-3}$ in monsoon. Using this method SOC/OC ratios accounted for 53.4 to $78.4 \%$ of the OC, suggesting that SOC is an important component of PM ${ }_{2.5}$. It illuminated that SOC was an important component of OC mass in Tiruchirappalli city, presenting a significant trend of secondary transformation. Present high SOC/OC ratios in pre-monsoon were mainly due to the increased emission of volatile organic precursors and the adsorption and condensation of semi-volatile organic compounds onto existing solid particles under low temperature conditions, as well as enhanced SOC formation under the stagnated atmospheric condition (6) (44) .

\section{Total carbonaceous aerosol (TCA) to PM 2.5}

The annual average concentrations of total carbonaceous aerosol (TCA) were $20.27 \pm 6.0,11.10 \pm 2.47,15.25 \pm 4.78$, and $27.05 \pm 5.23 \mu \mathrm{g} \cdot \mathrm{m}^{-3}$ in winter, summer, pre-monsoon, and monsoon respectively. Also, which accounted for $23.54 \%, 22.47 \%$, $20.81 \%$, and $30.78 \%$ of $\mathrm{PM}_{2.5}$ mass, respectively, implying that TCA contributed a major fraction of $\mathrm{PM}_{2.5}$ mass in Tiruchirappalli.

\section{CONCLUSIONS}

The mass concentrations of $\mathrm{PM}_{2.5}$ were $86.1 \pm 13.6 \mu \mathrm{g} / \mathrm{m}^{3}$ in winter, $45.9 \pm 25.6 \mu \mathrm{g} / \mathrm{m}^{3}$ in summer, $73.3 \pm 27.5 \mu \mathrm{g} / \mathrm{m}^{3}$ in in $\mathrm{pre}$ monsoon and $87.9 \pm 25.3 \mu \mathrm{g} / \mathrm{m}^{3}$ in monsoon, respectively, indicating the serious circumstances of fine particle pollution in Tiruchirappalli. Similarly, the mass concentrations of OC, EC and WSOC were observed in $8.95 \mu \mathrm{g} / \mathrm{m}^{3}, 4.10 \mu \mathrm{g} / \mathrm{m}^{3}$ and $3.1 \mu \mathrm{g} / \mathrm{m}^{3}$ respectively. On seasonal average, $\mathrm{PM}_{2.5}$, OC, EC and WSOC concentrations ranked in the order of monsoon > winter > pre-monsoon > summer. In comparison with other cities in India the $\mathrm{PM}_{2.5}$ concentrations in Tiruchirappalli were at moderately high level. The annual average value of OC/EC ratios in this study observed 2.5, which indicates that carbonaceous fractions in Tiruchirappalli were emitted from mixed sources such as Vehicular exhaust, biomass burning and road side restaurants etc. Annual average OC concentrations accounted about $70 \%$ in TCA, which illuminated that OC was the main fraction of TCA. Moreover, annual average SOC concentrations accounted for about $74 \%$ in OC suggesting that SOC is an important component of $\mathrm{PM}_{2.5}$. The source characteristics of $\mathrm{PM}_{2.5}$ and carbonaceous species in different seasons were examined using OC/EC, WSOC/OC ratio methods. The present assessment of $\mathrm{PM}_{2.5}$ and carbonaceous species of $\mathrm{PM}_{2.5}$ is the first step to determine the health and safe limit on human beings, which will be evaluated in future and this kind of studies are yet to be developed for Tiruchirappalli city. A need for inventory of air trajectory within canyon and implementation of good practices such as land use policy and vehicular emission control is imperative. 


\section{ACKNOWLEDGEMENTS}

The authors gratefully thank PG \& Research Department of Chemistry, Jamal Mohamed College (Autonomous), Tiruchirappalli-620 020 for keen interest and support for the study.

\section{REFERENCES}

[1]. Huang Han, L., Zhou, W., Li, W., Li, L.,. Impact of urbanization level on urban air quality: a case of fine particles (PM 2.5) in Chinese cities. Environmental Pollution. 194, 163-170. 2014.

[2]. Kanakidou, M., Mihalopoulos, N., Kindap, T., Im, U., Vrekoussis, M., Gerasopoulos, E. \&Melas,D.Megacities as hot spots of air pollution in the East Mediterranean. Atmospheric Environment, 45(6), 1223-1235.2011.

[3]. Black, D., Black, J., A review of the urban development and transport impacts on public health with particular reference to Australia: Transdisciplinary research teams and some research gaps. International journal of environmental research and public health. 6(5), 1557-1596. 2009.

[4]. Zhao, H., Che, H., Zhang, X., Ma, Y., Wang, Y., Wang, H., \& Wang, Y. Characteristics of visibility and particulate matter (PM) in an urban area of Northeast China. Atmospheric Pollution Research, 4(4), 427-434.2013.

[5]. Zhang, F.W. Zhao, J.P. Chen, J.S. Xu, Y. Xu, L.L. Pollution characteristics of organic and elemental carbon in PM2.5 in Xiamen, China. J. Environ. Sci., 23, 1342-1349.2011.

[6]. Central Pollution Control Board, . Ambient air quality status of India-2007.

[7]. Jimoda, L.A. Effects of particulate matter on human health, the ecosystem, climate and materials: a review. Facta universitatis-series: Working and Living Enviromental Protection, 9(1), 27-44.2012

[8]. Fuzzi, S., Baltensperger, U., Carslaw, K., Decesari, S., Denier Van Der Gon, H., Facchini, M. C., Nemitz, E. Particulate matter, air quality and climate: lessons learned and future needs. Atmospheric chemistry and physics, 15(14), 8217-8299. 2015.

[9]. Gu, J., Bai, Z., Liu, A., Wu, L., Xie, Y., Li, W., Characterization of Organic Carbon and Element Carbon of PM 2.5 and PM 10 at Tianjin, China. Aerosol and Air Quality Research, 10: 167-176, 2010 doi: 10.4209/aaqr.2009.12.0080.2008.

[10]. Jacobson, M.Z., Strong radiative heating due to the mixing state of black carbon in atmospheric aerosols. Nature. 409, 695-697.2001

[11]. Hing-Cho Cheung, Tao Wang, Karstern Baumann, Hai Guo.Influence of regional pollution outflow on the concentrations of fine particulate matter and visibility in the coastal area of southern China.https://doi.org/10.1016/j.atmosenv.07.033.2005.

[12]. Decesari, S., Fuzzi, S., Facchini, M. C., Mircea, M., Emblico, L., Cavalli, F., et al., Characterization of the organic composition of aerosols from Rondônia, Brazil, during the LBA-SMOCC 2002 experiment and its representation through model compounds. Atmospheric Chemistry and Physics, 6(2), 375-402.2006.

[13]. K Kumagai, A Iijima, H Tago, A Tomioka, Seasonal characteristics of water-soluble organic carbon in atmospheric particles in the inland Kanto plain, Japan. Atmospheric Environment https://doi.org/10.1016/j.atmosenv 04.008.2009.

[14]. Sharma, M., and Maloo, S.Assessment of ambient air PM10 and PM2.5 and characterization of PM10 in the city of Kanpur, India. Atmos. Environ. 39, 6015-6026.2005.

[15]. Sudheer, A.K. and Sarin, M.M.:Carbonaceous aerosols in MABL of Bay of Bengal: influence of continental outflow, Atmos. Environ., 42, 4089-4089-4100,2008.

[16]. Ram, K., Sarin, M.M., Hegde, P.Atmospheric abundances of primary and secondary carbonaceous species at two high-altitude sites in India: sources and temporal variability. Atmos. Environ. 42, 6785-6796.2008

[17]. Satsangi, A., Pachauri, T., Singla, V., Lakhani, A., Kumari, K.M. Organic and elemental carbon aerosols at a suburban site. Atmos. Res. 113, 13-21.2012.

[18]. Ram, K. and Sarin, M.M. Day-night variability of EC, OC, WSOC and inorganic ions in urban environment of Indo-Gangetic Plain: Implications to secondary aerosol formation. Atmos. Environ. 45: 460-468.2011.

[19]. Horaginamani, S.M., Ravichandran, M., Ambient air quality in an urban area and its effects on plants and human beings: a case study of Tiruchirappalli, India. Kathmandu University Journal of Science, Engineering and Technology. 6(2), 13-19.2010.

[20]. World Health Organization (WHO) Global Urban Ambient Air Pollution Database .2016

[21]. Xu, L.,Chen, X., Chen, J., Zhang, et al., Seasonal Variations and chemical compositions of PM2.5 Aerosol in the urban Area of Fuzhou, China. Atmos.Res.104-105:264-272.2012.

[22]. C. Arden Pope III, ; Richard T. Burnett, et al; Eugenia; Daniel Krewski, ; Kazuhiko Ito,; George D. Thurston(2002) Lung Cancer, Cardiopulmonary Mortality, and Long-term Exposure to Fine Particulate Air Pollution JAMA.287(9):1132-1141. doi:10.1001/jama.287.9.11.2002.

[23]. C. Arden Pope III \&Douglas W. Dockery .Health Effects of Fine Particulate Air Pollution: 2006.

[24]. Ambade, B., Physico-chemical assessment of rain, fog and runoff water. Lap-Lambert Academic Publishing, Saarbrucken. ISBN 978-3-65930271-8.2012

[25]. Cao, M., Woodward, F.I., Dynamic responses of terrestrial ecosystem carbon cycling to global climate change. Nature. 393(6682), 249252.1998.

[26]. Wu, S.P., Schwab, J., Liu B.L., Li, T.C. and Yuan, C.S. Seasonal Variations and Source Identification of Selected organic Acids Associated with PM10 in the Coastal Area of Southeastern China. Atmos. Res 155:37-51.2015.

[27]. Louie, P.K.K., Chow, J.C., Chen, L.W.A., Watson, J.G., Leung, G.L., Sin, D.W.M. PM2.5 Chemical Composition in Hong Kong: Urban and Regional Variations. Sci. Total Environ. 338: 267-281.2005.

[28]. Heo, J.B., Hopke, P.K., Yi, S.M., Source Apportionment of PM2.5 in Seoul, Korea. Atmos. Chem. Phys. 9, 4957-4971.2009.

[29]. Ram, K., Sarin, M.M. Day-night variability of EC, OC, WSOC and inorganic ions in urban environment of Indo-Gangetic Plain: implications to secondary aerosol formation. Atmos. Environ. 45, 460-468.2011. 
[30]. Panicker, A.S., Kaushar, A., Gufran, B., Yadav, S. Characterization of particulate matter and carbonaceous aerosol over two urban environments in northern India. Aerosol Air Qual. Res. 15, 2584e2595. http://dx.doi.org/10.4209/aaqr.2015.04.0253.2015.

[31]. Pachauri, T., Singla, V., Satsangi, A., Lakhani, A. and Kumari, K.M. SEM-EDX characterization of individual coarse particles in Agra, India. Aerosol Air Qual. Res. 13: 523-536.2013.

[32]. Pipal, A.S., Tiwari, S., Satsangi, P.G., Taneja, A., Bisth, D.S., Srivastava, A.K. and Srivastava, M .K. Sources and characteristics of carbonaceous aerosols at Agra "World heritage site" and Delhi "capital city of India. Environ. Sci. Pollut. Res. 21: 8678-8691.2014.

[33]. Pipal, A.S., Tiwari, S., Satsangi, P.G., Seasonal Chemical Characteristics of Atmospheric Aerosol Particles and its Light Extinction Coefficients over Pune, India. Aerosol and Air Quality Research. 16(8), 1805-1819.2016.

[34]. Park, S.S., Cho, S.Y. (2011). Tracking sources and behaviors of water-soluble organic carbon in fine particulate matter measured at an urban site in Korea. Atmospheric environment, 45(1), 60-72.2011.

[35]. Huang, X. F., Yu, J. Z., He, L. Y., Yuan, Z.Water-soluble organic carbon and oxalate in aerosols at a coastal urban site in China: size distribution characteristics, sources, and formation mechanisms. Journal of Geophysical Research: Atmospheres, 111(D22).2006.

[36]. Ram, K., Sarin, M.M. Hegde, P.Long-term Record of Aerosol Optical Properties and Chemical Composition from a High-altitude Site (Manora Peak) in Central Himalaya. Atmos. Chem. Phys. 10: 11791-11803.2010.

[37]. Psichoudaki, M., \& Pandis, S. N .Atmospheric aerosol water-soluble organic carbon measurement: a theoretical analysis. Environmental science \& technology, 47(17), 9791-9798.2013.

[38]. Kaul, D.S., Gupta, T., Tripathi, S.N., Tare, V., Collett, J.L. Secondary organic aerosol: a comparison between foggy and nonfoggy days. Environ. Sci. Technol. 45, 7307-7313.2011.

[39]. Sandradewi, I., Prevot, A.S.H., Weingartner, E., Schmidhauser, et al., A study of wood burning and traffic aerosol in an Alpine valley using a multi-wavelength Aethalometer. Atmospheric Environment, 42, 101-112.2008.

[40]. Chow, J.C., Watson, J.G., Lu, Z., Lowenthal, D.H., Frazier, C.A., Solomon, P.A., Richard H.T., Karen, M., Descriptive analysis of PM2.5 and PM10 at regionally representative locations . Atmospheric Environment. 30 (12), 2079-2112.1996.

[41]. Saxena, P., Hildemann, L. M. Water-soluble organics in atmospheric particles: A critical review of the literature and application of thermodynamics to identify candidate compounds. Journal of atmospheric chemistry, 24(1), 57-109.1996.

[42]. Min-SukBae,Chun-SangHong,YoungJ.Kim,Jin-SeokHan,YuzoMiyazaki,et.al.Inter comparison of two different thermal-optical elemental carbons and optical black carbon.J.Atmo.Senv.11.040.2007.

[43]. Yuzo Miyazaki ,Shankar G. Aggarwal ,Khem Singh ,Prabhat K. Gupta ,Kimitaka Kawamura.Dicarboxylic acids and water-soluble organic carbon in aerosols in New Delhi, India, in winter: Characteristics and formation processes. https://doi.org/10.1029/2009JD011790.2009.

[44]. ChunleiCheng,GehuiWang,JingjingMeng,QiyuanWang,JunjiCao,JianjunLi,JiayuanWang.Size-resolved airborne particulate oxalic and related secondary organic aerosol species in the urban atmosphere of Chengdu, China.J.Atmos.Res.04.010.2015.

[45]. Yanli Feng , Yin gjunChen, et al., Characteristics of organic and elemental carbon in PM 2.5samples in Shanghai, China.J.Atmos. Res.01.003.2009.

[46]. He, K.B., Yang, F.M., Ma, Y.L., Zhang, Q., Yao, X.H., Chan, C.K., Cadle, S., Chan, T., Mulawa, P., The characteristics of PM2.5 in Beijing, China. Atmos. Environ. 35, 4959-4970.2001. 